\title{
Biomphalaria species distribution and its effect on human Schistosoma mansoni infection in an irrigated area used for rice cultivation in northeast Brazil
}

\author{
Delmany Moitinho Barboza ${ }^{1}$, Cangjie Zhang ${ }^{2}$, Nathaly Cardoso Santos ${ }^{3}$, Marília Matos \\ Bezerra Lemos Silva ${ }^{3}$, Carla Virgínia Vieira Rollemberg ${ }^{1}$, Fabio Jorge Ramalho de Amorim ${ }^{1}$, \\ Marlene Tiduko Ueta ${ }^{5}$, Claudia Moura de $\mathrm{Melo}^{2}$, José Antônio Pacheco de Almeida ${ }^{3}$, \\ Verónica de Lourdes Sierpe Jeraldo ${ }^{2 \dagger}$, Amélia Ribeiro de Jesus ${ }^{1,4 \dagger}$ \\ ${ }^{1}$ Laboratório de Biologia Molecular, Departamento de Medicina, Hospital Universitário, Universidade Federal \\ de Sergipe, Rua Clándio Batista, s/n, Hospital Universitário, 49.060-100, Aracaju, Sergipe, Brazil; ${ }^{2}$ Instituto de \\ Tecnologia e Pesquisa, Universidade Tiradentes (UNIT), Aracaju, Sergipe, Brazil; ${ }^{3}$ Departamento de Geologia. \\ Pós-Graduação em Geografia, Universidade Federal de Sergipe, Aracaju, Sergipe, Brazil; ${ }^{4}$ Instituto de \\ Investigação em Imunologia, Institutos Nacionais de Ciência e Tecnologia (INCT), CNPq, Brazil; \\ ${ }^{5}$ Departamento de Biologia Animal, Universidade Estadual de Campinas, São Paulo, Brazil; ${ }^{\dagger}$ Verónica de \\ Lourdes Sierpe Jeraldo and Amélia R. de Jesus share the senior authorship.
}

\begin{abstract}
The role of irrigated areas for the spread of schistosomiasis is of worldwide concern. The aim of the present study was to investigate the spatial distribution of the intermediate snail host Biomphalaria in an area highly endemic for schistosomiasis due to Schistosoma mansoni, evaluating the relationship between irrigation and types of natural water sources on one hand, and the influence of place and time of water exposure on the intensity of human infection on the other. A geographical information system (GIS) was used to map the distribution of the intermediate snail hosts in Ilha das Flores, Sergipe, Brazil, combined with a clinical/epidemiological survey. We observed a direct correlation between the intensity of human infection with $S$. mansoni and irrigation projects. Malacological studies to identify snail species and infection rates showed that $B$. glabrata is the main species responsible for human schistosomiasis in the municipality, but that $B$. straminea also plays a role. Our results provide evidence for a competitive selection between the two snail species in rice fields with a predominance of B. glabrata in irrigation systems and B. straminea in natural water sources.
\end{abstract}

Keywords: Biomphalaria glabrata, Biomphalaria straminea, Schistosoma mansoni, geographical information system, irrigation, system, natural water sources, Brazil.

\section{Introduction}

Schistosoma mansoni, a trematode worm that is endemic in 54 countries, is widespread in Africa and also occurs in Latin America. In Brazil, 42.9 million people are estimated to be at risk of contracting schistosoma sis and 6.8 million are infected (WHO, 2010; Scholte et al., 2012). This parasite occurs in 18 states including the Federal District and is most prevalent in the northeast, the southeast and the midwest (Brazil, 2009). In the northeast, Biomphalaria straminea and

\footnotetext{
Corresponding author:

Amélia Maria Ribeiro de Jesus

Laboratório de Biologia Molecular

Hospital Universitário Universidade Federal de Sergipe

Rua Cláudio Batista, S/N. Bairro Sanatório, Aracaju, Sergipe, Brazil CEP: 49045-100

Tel. +79 210 51806; Fax +79 21051811

E-mail: jesus-amelia@uol.com.br
}

B. glabrata are the snail intermediate host species responsible for transmission. The municipality of Ilha das Flores has the highest prevalence of schistosomiasis in the state of Sergipe, 46.5\% (Rollemberg et al., 2011). This municipality has a furrow, irrigable perimeter of 2,600 ha used for rice production, which not only provides the local population with a multitude of water sources but also presents multiple opportunities for infection with Schistosoma mansoni. Many studies have described the impact of the introduction of irrigation and the onset of increased prevalence rates of schistosomiasis (Amin, 1976; Mobarak, 1982; Barbosa and Costa, 1985; Huang and Manderson, 1992; Carmo and Barreto, 1994). A large number of studies using geographical information systems (GIS) have mapped the spatial distribution and expansion of the snail intermediate hosts contributing to a better understanding of transmission dynamics, helping the schistosomiasis control programme (SCP) 
to mount necessary countermeasures (reviewed by Gazzinelli and Kloos, 2007). However, most studies used secondary data collected by the SCP and did not associate malacological studies with clinical and epidemiological data.

With the aim to better understand the factors involved in the maintenance of high prevalence of schistosomiasis, we investigated an endemic area characterized by strong transmission. GIS was used to map the spatial relationship between water sources and the breeding capability of the two main snail species involved in transmission of the disease locally. We also investigated the influence of the place and time of water exposure in the intensity of human infection.

\section{Materials and methods}

\section{Study design and endemic area}

A cross-sectional, epidemiological study was carried out by combining GIS methodology with parasitological and epidemiological surveys and a malacological investigation in Ilha das Flores municipality, located $135 \mathrm{~km}$ from the capital Aracaju in the state of Sergipe. This municipality, located at an altitude of 28 meters above the mean sea level (MSL), is one of the major producers of rice in the northeast, where it saddles the banks of the São Francisco River around the geographic coordinates $10^{\circ} 26^{\prime} 05^{\prime}$ 'South and $36^{\circ} 32^{\prime} 21$ ” West. In the Brazilian Geodetic System, which uses the Universal Transverse of Mercator (UTM) projection, the area is located in Meridian Zone 24.

Ilha das Flores has 8,568 inhabitants, $85.4 \%$ of whom have access to tap water (however only intermittently). Only $3.3 \%$ of the urban population has sanitation coverage (IBGE, 2007). The irrigation project takes its water from the local river with a system based on two pumping stations, one located in the city and the other in the village of Serrão. The irrigation canals are largely used by the local people for a number of activities (e.g. car washing, bicycle cleaning, playing with animals, leisure, household tasks and fishing). After irrigating the rice fields, the water is drained through a stream back into the São Francisco River. Many of these drains also receive waste from open sewers coming from houses in the vicinity. In the rainy season, the irrigation system overflows flooding rice fields, streams, fish ponds and also the streets spreading Biomphalaria snails around the whole municipality.

\section{Creation of a georeferenced database}

Aerial photographs at the 1:25,000-scale from 2003 were obtained from the State Planning Department (SEPLAN) and a panchromatic satellite image of 2.7 $\mathrm{m}$ resolution from the Sino-Brazilian satellite CBERS 2B came from the National Institute for Space Research (http://www.inpe.br). Georeferencing was carried out based on images and photos through the acquisition of control points in environment with a hand-held global positioning system (GPS) instrument (Trimble - Juno ST) with an accuracy of $2.5 \mathrm{~m}$ after correction. The georeference database was created using SPRING 5.0 (National Institute for Space Research; http://www.inpe.br) and ArcGIS, version 9.3 (ESRI, Redlands, CA, USA). The resulting cartographic base contained maps of urban and rural areas, water sources and land use of the main thematic classes.

\section{Water contact and parasitological examination}

A parasitological and epidemiological survey was carried out from 2008 to 2010. A sample of the population including 500 inhabitants was randomly selected among 100 houses in this endemic area. The sample size was calculated based on the $40 \%$ prevalence rate and a $95 \%$ confidence interval (CI) of 35.7$44.4 \%$, determined by the SCP from the State Health Department. This project was approved by Sergipe's University Hospital ethics committee, Brazil (UFS number-CAAE 0103.0.107.107-09). All participants, including those responsible for minors, signed a consent form. Place and time of water contact was annotated. Parasitological examintiona were carried out by the Kato-Katz technique (Katz et al., 1972) and Three Fecal Tests (TF) methods (Immunoassay Ind. Com. Ltda., São Paulo, Brazil).

\section{Malacological study}

The malacological study was conducted from September 2009 to October 2010 and performed monthly. The presence of water sources in the city and in the villages belonging to the municipality was identified by analysis of the aerial photographs. Nine collection points for Biomphalaria were selected with the aim of reaching the largest possible coverage area where cases of schistosomiasis had been confirmed through the parasitological survey. The water sources were marked as collection points after their identification in the environment using GPS and digital pictures.

The snail collections were carried out by two trained 
persons using a metal shell and wood tweezers to scan for snails in the radius of approximately $10 \mathrm{~m}$ for 45 min. The captured snails were placed in plastic boxes containing food and water, identified by date, location, type of water source and collection point. They were subsequently transported to the laboratory and the number of captured snails calculated, their species classified and the tissues tested for S. mansoni infection. For species identification, we used the technique of dissecting the snail genital tract (Deslandes, 1951) and morphological evaluation of the shell (Paraense, 1961, 1975; Barbosa, 1995). In order to verify S. mansoni infection, we used the traditional technique of exposure to light that stimulates the sheding of cercariae (Souza and Lima, 1990).

\section{Statistical analysis}

Statistical analysis was performed using software Graphped Prisma. Differences between groups were calculated using Mann-Whitney test (Wilcoxon, 1945; Mann and Whitney, 1947). Correlation tests were carried out using the Spearman method (Spearman, 1904). A value of $5 \%$ was considered for statistical significance.

\section{Results}

The aerial photograph used to delineate the urban and rural areas of Ilha das Flores, including the irrigation system and the collection points (water sources), is shown in Figure 1.
Table 1 presents the areas surveyed, the types of water source and the Biomphalaria species found, including the number of times they were found and whether or not they were infected. Out of the nine water sources surveyed, four were rice fields, two seasonal ponds, one a stream, one an irrigation drain and one an irrigation canal. Mollusks of the genus Biomphalaria, 16,851 specimens overall, were collected from the nine collection points within the 12-month collection period. A predominance of B. glabrata was found in this area. From the total number of Biomphalaria captured, $30.3 \%$ were of the specie B. straminea and $69.7 \%$ B. glabrata. Of this total, 230 were naturally infected by $S$. mansoni, $24.3 \%$ of B. straminea and $75.7 \%$ of B. glabrata. Additionally, infected B. glabrata was identified during each of the 12 collection time points in contrast to B. straminea.

B. glabrata specimens were found in three rice fields, in one canal and in one irrigation drain, whereas $B$. straminea specimens were found in two seasonal ponds, in one rice field and in one stream. A higher number of Biomphalaria snails was collected in the rice fields and irrigation drains. When the distribution of $B$. straminea and B. glabrata snails collected in nine water sources was analysed, no overlap between the two species was observed at any point of collection, demonstrating biological competition between them. B. straminea specimens were found in natural water sources and rice fields and B. glabrata snails only in water sources from the irrigation system and rice fields (Fig. 2).

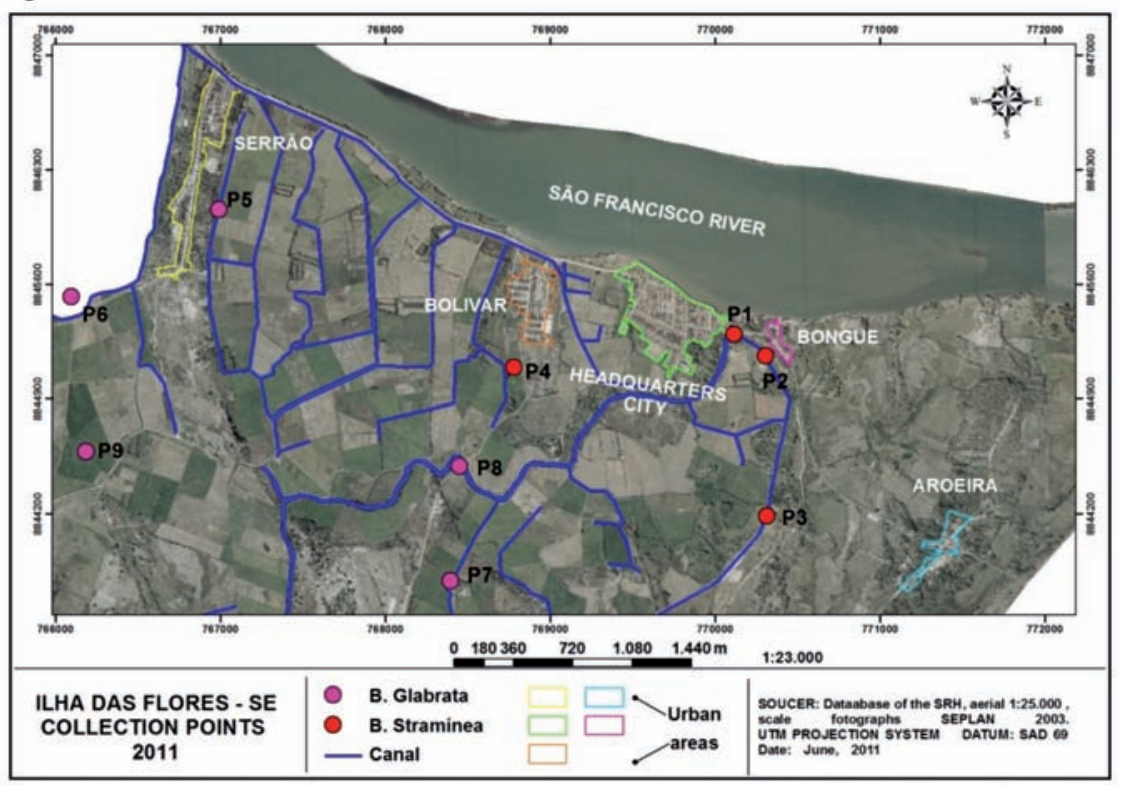

Fig. 1. Georeferenced aerial photograph of Ilha das Flores showing the urban and rural areas with the location of collection points of Biomphalaria and the irrigation system. 
Table 1. Characterization of places where Biomphalaria were collected in the endemic area of Ilha das Flores from September 2009 to October 2010.

\begin{tabular}{cllcc}
\hline Collection points & Water sources & Biomphalaria species & $\begin{array}{c}\text { Number of times } \\
\text { we collected snails (/12) }\end{array}$ & $\begin{array}{c}\text { Number of times } \\
\text { we collected infected snails (/12) }\end{array}$ \\
\hline P1 & Stream & B. straminea & 4 & 2 \\
P2 & Seasonal ponds & B. straminea & 11 & 3 \\
P3 & Rice field & B. straminea & 12 & 8 \\
P4 & Seasonal ponds & B. straminea & 10 & 5 \\
P5 & Rice field & B. glabrata & 12 & 6 \\
P6 & Irrigation canal & B. glabrata & 12 & 9 \\
P7 & Rice field & B. glabrata & 10 & 4 \\
P8 & Irrigation drain & B. glabrata & 10 & 8 \\
P9 & Rice field & B. glabrata & & 4 \\
\hline
\end{tabular}

We observed a direct correlation between the number of captured and infected B. glabrata (Spearman, $\mathrm{r}$ $=0.50 ; 95 \% \mathrm{CI}=0.27-0.67 ; \mathrm{P}<0.001)$, which allowed us to infer that the greater the number of snails found, the greater the number of infected ones. This was not true for B. straminea (Spearman, $\mathrm{r}=0.24 ; 95 \% \mathrm{CI}=$ 0.06-0.50; $\mathrm{P}=0.099$ ) (Fig. 3).

We also investigated the association between the B. straminea and B. glabrata species, their numbers and their rates of infection by $S$. mansoni with respect to harvest season and off-season. Considering all water sources together, a higher number of B. straminea snails was captured in the harvest season

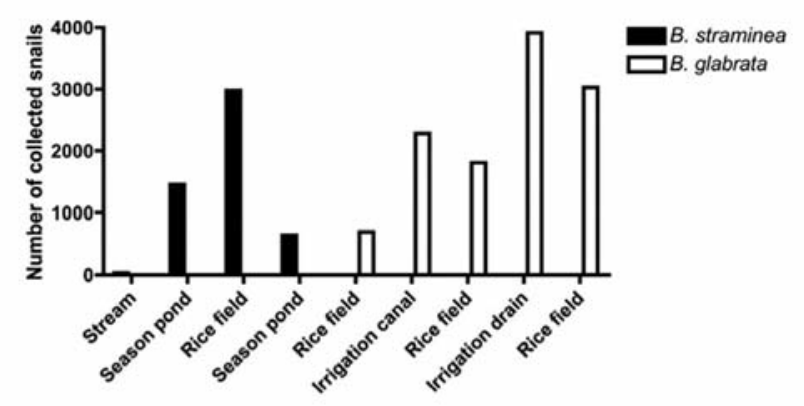

Fig. 2. Distribution of B. straminea and B. glabrata collected in nine analysed water sources. than in the off-season $(\mathrm{P}=0.004$, Mann-Whitney test). There was also a more significant number of infected B. glabrata specimens than infected B. straminea snails during the harvest season $(\mathrm{P}=0.007$, MannWhitney test) (Fig. 4). In general, not only water sources related to the irrigation system (i.e. rice fields, irrigation canals and drains) contained more captured Biomphalaria but also more infected ones (Fig. 5).

In an attempt to determine the influence of the irrigation system on human infection, we performed a correlation analysis between time of water contact and human infection intensity as expressed by the number of eggs/g of stool (EPG). Although there was no correlation between the EPG level and the number of hours of water contact in any of the water sources (Spearman $\mathrm{r}=0.0, \mathrm{P}=0.64$ ) (Fig. 6A) when only exposure to water sources related to the irrigation system was considered, a direct correlation between the EPG value and the number of hours of water contact in general was observed (Spearman $r=0.21, P=0.02$ ) (Fig. 6B).

Discussion

The evidence for B. glabrata being more involved in $S$. mansoni transmission than B. straminea in Ilha das
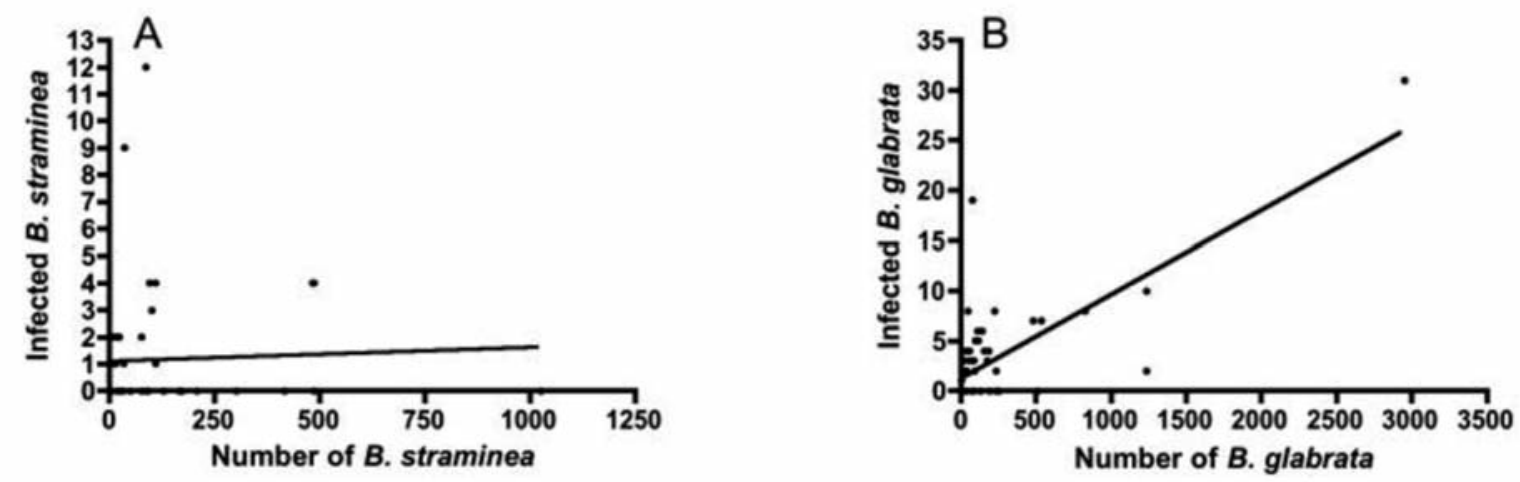

Fig. 3. Correlation between the numbers of captured and infected B. straminea (A) and B. glabrata (B) snails. (A) Spearman $\mathrm{r}=$ $0.24, \mathrm{P}=0.099$; (B) Spearman $\mathrm{r}=0.50, \mathrm{p}<0.0 \leq 0.001$. 

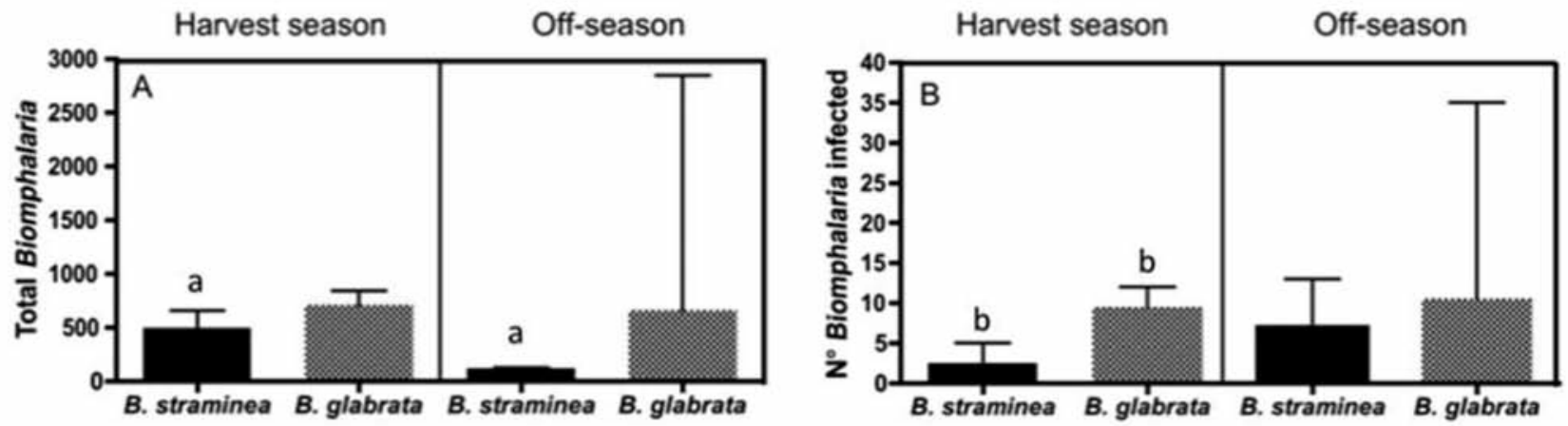

Fig. 4. The numbers of Biomphalaria snails collected (A) and infected (B) according to the period of rice culture, harvest season (September 2009 to February 2010 and August 2010 to October 2010) and off-season (March 2010 to July 2010). ${ }^{a} \mathrm{P}=0.004$; ${ }^{\mathrm{t}} \mathrm{P}=0.007$; Mann-Whitney test.
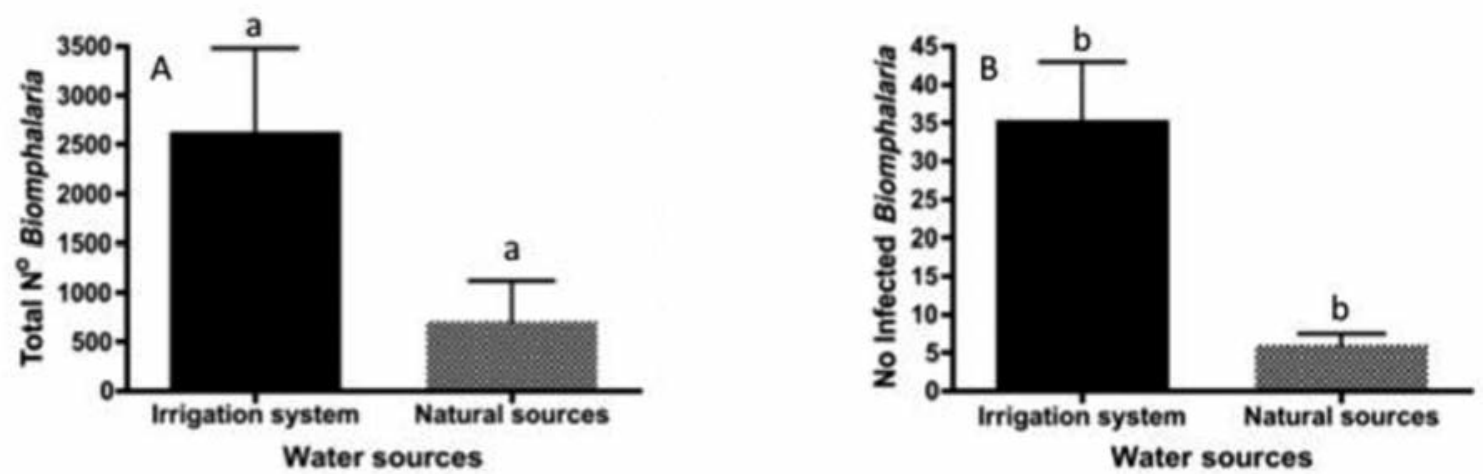

Fig. 5. The numbers of Biomphalaria snails captured (A) and naturally infected by S. mansoni (B) according to water sources surveyed at irrigation systems or natural sources. Mann-Whitney test ${ }^{\mathrm{a}} \mathrm{P}=0.047$ and ${ }^{\mathrm{b}} \mathrm{P}=0.023$.

\section{Any water sources}

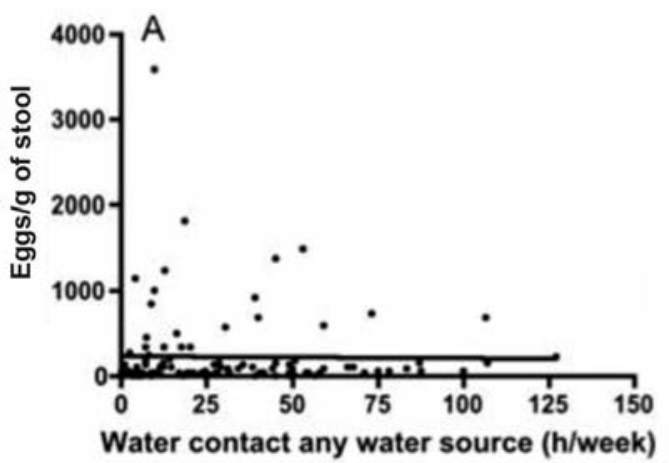

\section{*Irrigation water sources}

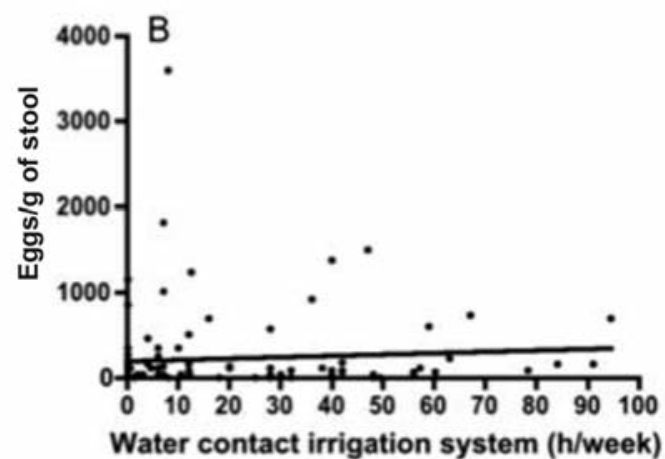

Fig. 6. Correlation between the number of hours of water contact in any water sources (A), Spearman $r=-0.04, P=0.64$; and in the irrigation water sources (rice field, canal and drain) (B), Spearman $\mathrm{r}=0.21, \mathrm{P}=0.02$.

Flores is based on the following findings:

(i) B. glabrata snails were more frequently found and also more often infected than $B$. straminea snails;

(ii) the greater the number of B. glabrata specimens found, the greater the number of infected ones;

(iii) B. glabrata was predominately found in rice fields and the irrigation system, while $B$. straminea was predominately found in natural water sources; and

(iv) the water sources related to the irrigation presented higher numbers of snails than the natural water sources.

The two species seem to be in the process of competitive displacement because in each of the collection 
points only one of the species was found. There is now a predominance of B. glabrata over B. straminea in the study area. However, Mello and Barbosa (1969) and Figueiredo (1989) collected snail samples in this region of the backwoods of the São Francisco River valley and showed that $B$. straminea was the exclusive species found. Our data showing the predominance of B. straminea in natural water sources is indicative that this species is the natural snail found in the area, and that B. glabrata has overpowered B. straminea after the irrigation system was created in 1967. As B. glabrata is less resistant to dry weather conditions than $B$. straminea, the irrigation system promotes survival of the former species by changing the environment by enriching the soil with nutrients and water.

The data from the SCP from 2007 show a prevalence of $45.5 \%$. This study shows that the irrigation and rice cultivation have an effect on the intensity of human infection by $S$. mansoni. We also show a correlation between the levels of $S$. mansoni infection and the time of activities in water sources related to the irrigation system, confirming the influence of these activities on the infection levels. This knowledge is important for understanding the process of natural selection responsible for the establishment of schistosomiasis in new areas that could potentially lead to future control designs based on natural, biological control. Snails are severely affected by $S$. mansoni infection resulting in a reduced lifespan. The particularly high susceptibility of $B$. glabrata snails to infection might be a selective disadvantage for this species that might lead to its replacement by $B$. straminea. Indeed, it has been shown that $B$. straminea replaces B. glabrata both in the natural environment and under laboratory conditions (Coelho, 1954; Barbosa, 1973; Michelson and Dubois, 1979; Figueiredo, 1989; Barbosa et al., 1993). However, in this area, we demonstrate that under specific environmental conditions due to irrigation, $B$. glabrata became the major species responsible for human $S$. mansoni infection.

A possible biological control of the disease could be implemented by reducing the replacement of the native snail populations in newly irrigated areas, or even repopulating areas with a predominance of B. glabrata with $B$. straminea or other snail species, less susceptible or resistant to $S$. mansoni infection. Indeed, this process occurred in Martinique where the substitution of B. glabrata for B. straminea interrupted transmission of schistosomiasis (Guyard and Pointier, 1979, 1982; Pointier, 1982, 1983). Indeed, it is known that $B$. straminea withstands desiccation better, has a greater ability of dispersal and fecundity, with consequently greater aggressiveness to invade territories occupied by $B$. glabrata.

It should also be pointed out that irrigation is an important tool for the maintenance of more stable and productive agricultural schemes, and that also other factors participate in the determination of the presence or absence of the schistosomiasis, e.g.:

(i) the type of irrigation system (intensive, mechanized, requiring little manual labour or widespread, non-mechanized and labour intensive);

(ii) the relationship between humans and the environment (the cultural and behavioural practices of the population with respect to water resources); and

(iii) socio-economic factors, which can increase environmental contamination of water sources (Barreto, 1982; Smith, 1988; Lima, 1995).

A study in Bahia, Brazil (Martins and Barreto, 2003) showed that the municipalities with the largest irrigated areas are not those with the highest rates of prevalence of schistosomiasis, and that irrigation has had little impact on the spatial profile of the disease, unlike what is commonly observed in Africa. According to this study, the extensive type of irrigation system, when compared to the intensive one, greatly influences in the spread of the disease. In the study area, the extensive, non-mechanized irrigation favours the survival of B. glabrata over B. straminea species, which results in high transmission and high prevalence of schistosomiasis.

\section{Acknowledgements}

We thank the health agents, Jorge Feitosa and Edmilson N. dos Santos and the Coordinator of the Endemic Disease Control Programme, Mário C. Silva, the students Débora D. Barreto, Karina M. S. C. Pessoa, Nayanna M. N. Lessa, Cybele M. B. Santos and Cynthia C. G. Andrade. Financial support was from MS /CNPq/FAPITEC/ SE (PPSUS) and CAPES.

\section{References}

Amin AM, 1976. Problems and effects of schistosomiasis in irrigation schemes in the Sudan arida land irrigation in developing countries, environmental problems and effects. Pergamon Press, London, UK.

Barbosa CS, Barbosa FS, Arruda F, 1993. Long-term controlled field experiment in the competition between of Biomphalaria (Mollusca Basommatophora), the snail vectors of Schistosoma mansoni in Northeastern Brazil. Cad Saude Publica 9, 170-176. Barbosa F, Costa DP, 1985. A esquistossomose e o nordeste semi-árido. I - O estudo preliminar. Cad Saude Publica 1, 153- 
159.

Barbosa FS, 1973. Possible competitive displacement and evidence of hybridization between two Brazilian species of planorbid snails. Malacologia 14, 401-408.

Barbosa FS, 1995. Tópicos em malacologia médica. Fundação Oswaldo Cruz, 314 pp.

Barreto ML, 1982. Esquistossomose mansônica: distribuição da doença e organização social do espaço. Dissertação de Mestrado, Salvador: Departamento de Medicina Preventiva, Universidade Federal da Bahia, Brazil.

Brazil, 2009. Guia de vigilância epidemiológica. Brasília: Normas e Manuais Técnicos. Ministério da Saúde. 816 p.

Carmo EH, Barreto ML, 1994. Esquistossomose mansônica no estado da Bahia: tendências históricas e medidas de controle. Cad Saude Publica 10, 425-439.

Coelho MV, 1954. Ação das formas larvárias de Schistosoma mansoni sobre a reprodução de Australorbis glabratus. Publicações Avulsas do Instituto Aggeu Magalhães 3, 39-54.

Deslandes N, 1951. Técnica de dissecação e exame de planorbídeos. Rev. S. E. S. P., 371-382.

Figueiredo CCSB, 1989. Dispersão de Biomphalaria straminea no estado de Sergipe: um estudo comparativo com dezenove anos de intervalo. Mem Inst Oswaldo Cruz 84, 383-387.

Gazzinelli A, Kloos H, 2007. The use of spatial tools in the study of Schistosoma mansoni and its intermediate host snails in Brazil: a brief review. Geospat Health 2, 51-58.

Guyard A, Pointier JP, 1979. Faune malacologique dulçaquicole et vecteurs de la schistosome intestinale en Martinique. Ann Parasit Hum Comp 54, 193-205.

Guyard A, Pointier JP, 1982. Le role de la competition avec Biomphalaria straminea et B. glabrata dans le declin de la schistosomose intestinale en Martinique (Antilles Françaises). Proceedins of the 8th International Malacological Congress, Budapest, Hungary.

Huang Y, Manderson L, 1992. Schistosomiasis and the social patterning of infection. Acta Trop 51, 175-194.

Katz N, Chaves A, Pellegrino J, 1972. A simple device for quantitative stool thick-smear technique in Schistosomiasis mansoni. Rev Inst Med Trop São Paulo 14, 397-400.

Lima VLC, 1995. A esquistossomose urbana e a heterogeneidade social e epidemiológica da população do município de Campinas, São Paulo, Brazil. Cad Saude Publica 11, 45-56.

Mann HB, Whitney DR, 1947. On a test whether one of two random variables is stochastically larger than the other. Ann Math Stat 18, 50-60.
Martins DF, Barreto ML, 2003. Aspectos macroepidemiológicos da esquistossomose mansônica: análise da relação da irrigação no perfil espacial da endemia no Estado da Bahia, Brasil. Cad Saude Publica 19, 383-393.

Mello DA, Barbosa FS, 1969. Estudos sobre os planorbídeos transmissores da esquistossomose mansônica no estado de Sergipe. Gaz Med Trop 21, 246-253.

Michelson EH, Dubois L, 1979. Competitive interactions between two snails hosts of $S$. mansoni. Laboratory studies on B. glabrata and B. straminea. Rev Inst Med Trop São Paulo 21, 246-253.

Mobarak AB, 1982. The schistosomiasis problem in Egypt. Afr J Trop Med Hyg 31:87-91.

Paraense WL, 1961. Shell versus anatomy in planorbid systematic. I: Australorbis glabratus. Rev Bras Biol 21, 163-170.

Paraense WL, 1975. Estado atual da sistemática dos planorbídeos brasileiros. Arquivo do Museu Nacional 55, 105-111.

Pointier JP, 1982. Estude de la croissance de Biomphalaria glabrata mollusque hôte intermediaire de la schistosomose intestinale dans le forete marecagneses a Pterocarpus de Guadeloupe (Antilles Françaises). Malacologia 22, 395-398.

Pointier JP, 1983. La lutte biologique contre les mollusques hôtes intermediaires des bilharzioses a Láide de molusques competiteurs. Symbioses 15, 85-91.

Rollemberg CVV, Santos MB, Silva MMBL, Souza AMB, Silva AM, Almeida JAP, Almeida RP, Jesus AR, 2011. Epidemiological characteristics and geographical distribution of schistosomiasis and geohelminths, in the State of Sergipe, according to data from the Schistosomiasis Control Program in Sergipe. Rev Soc Bras Med Trop 44, 91-96.

Scholte RGC, Carvalho OS, Malone JB, Utzinger J, Vounatsou P, 2012. Spatial distribution of Biomphalaria spp., the intermediate host snails of Schistosoma mansoni in Brazil. Geospat Healt 6, S95-S101.

Smith N, 1988. Desenvolvimento desigual: natureza, capital e a produção do espaço. Rio de Janeiro: Bertrand.

Souza CP, Lima LC, 1990. Moluscos de interesse parasitológico do Brasil. Belo Horizonte: FIOCRUZ/CPqRR.

Spearman CD, 1904. Proof and measurement of association between two things. Am J Psychol 15, 72-102.

WHO, 2011. Schistosomiasis. Available at http://www.who.int/ neglected_diseases/preventive_chemotherapy/sch/db/index.ht $\mathrm{ml}$ ? (accessed on November 2011)

Wilcoxon F, 1945. Individual comparisons by ranking methods. Biometrics Bull 1, 80-83. 